\title{
CHINESE MUSLIMS' WAYS OF BEING NATIONALIST: COMBINING ISLAMIC COSMOPOLITANISM, ACCULTURATION AND SOCIAL ROLES
}

\author{
Achmad Muhibin Zuhri \\ UIN Sunan Ampel Surabaya \\ amizuhri@uinsby.ac.id \\ Winarto Eka Wahyudi \\ Islamic University of Lamongan (UNISLA) \\ ekawahyudi1926@unisla.ac.id \\ Abdulloh Hamid \\ UIN Sunan Ampel Surabaya \\ doelhamid@uinsby.ac.id
}

\begin{abstract}
One of the ideas that should also be formalized in the reform movement in Indonesia is addressing the issue related to minority groups. Chinese group in Indonesia is one of civil groups that may experience discrimination to date. As a minority ethnic and Muslim community in Indonesia, Chinese Muslims are inevitably in a vulnerable position. They should prove their patriotism toward the nation, Indonesia. This research finds out that the Chinese have been a community that exists way before Indonesia gained its independence: some even play a significant role in Islamization. Chinese Muslims in Indonesia also contribute to establishing the concept of nationalism in Indonesia. Additionally, Chinese Muslims seem to be successful
\end{abstract}


in contextualizing a more substantial concept of nationalism by positioning Chinese ethnic as a cultural entity, not as a representative of "other nation," and by assimilating local Muslims to play various societal roles. Besides, Chinese Muslims also practice moderate Islamic values to emphasize that their values do not contradict the national values of Indonesia.

Keywords: Chinese Muslim, Nationalist, Islamic Cosmopolitan, Acculturation, Social Roles

\section{A. Introduction}

Indonesia is known as a multi-ethnic state, but the racial sentiment has not hitherto been addressed in the public sphere. One of the issues is related to the Chinese existence in Indonesia. Many see the Chinese as a problem even back when Indonesia was under the Dutch invasion up to its Independence Day. The issue may arise due to the perpetuated stereotype about them. Some were seen as the pro-Dutch group, anti-nationalism, and exclusive (Hapsari, 2016). The discrimination against them also occurred in the national movement where Indische Partij, Communism Party of Indonesia, and Serikat Islam did not want any Chinese to join them (Mahfud, 2013). Recently, they have been seen as capitalists who are responsible the most for the confiscation of Indonesia's wealth. Conflicts between an ethnicity and local people may be triggered by the above situations (Kuo, 2018).

This study aims to depict the Chinese Muslims' ways of developing and actualizing patriotism. It also discusses the issues from the perspectives of nationalism that are more recent and substantial, i.e., to view the essential articulation of Chinese Muslims as a unique hybrid identity. A provisional conclusion is that hybrid identity will develop patriotism that 
is also unique: a combination of Islamic understanding, as well ascultural preservation and acculturation. This way tends to be more effective in overcoming the Chinese racial problems and articulating national characteristics as Chinese Muslims.

The existence of Chinese Muslims in Indonesia passes into a long history. In numerous epigraphs, the ethnicity moved from China gradually for thousand years ago. Qurtuby mentions that the close contact between Indonesia and Chinese dated back during the Ming Dynasty was in power (1368-1643 BC). Political relations may even be developed between the Ming Dynasty and the Majapahit Kingdom in Java (Al-Qurtuby, 2017).

The Chinese historical reality in Indonesia can be confirmed from the account of Ma Huan, a private secretary of Admiral Zheng Hee (1405 BC). He accompanied Zheng Hee three times in seven voyages in Nusantara. While visiting Trowulan, a small city in East Java, Ma Huan groups the Chinese into the following three social classes (Perkasa, 2012):

In Java, Chinese consists of $99.9 \%$ Hokkien. It can be drawn from those with clans such as Tan, Lim, Wei, Ong, and Cia as a characteristic of these clans. Ma Huan in his work Ying-Yai Sheng-Lan, as cited in Al-Qurtuby (2017), states that the Chinese have been in Java prior to the coming of Admiral Zheng Hee and living in the coastal area of northern Java (stretching from Tuban, Gresik, and Surabaya). They were originally from Kanton (Guangzhou), Zhangzhou, Quanzhou, and South China. From the above elaboration, it can be seen that the Chinese, during the Ming Dynasty (1368-1643 BC), have been in Indonesia even before its independence (AlQurtuby, 2017). 
From the cultural side, Chinese in Indonesia may not be a homogenous minority. Suryadinata (2010) categorizes Chinese into two groups: Peranakan (descendent) and Totok. Chinese Peranakan are those born in Indonesia with one of their parents is Indonesian, who tend not to be able to speak Chinese and speak the Indonesian or local language instead. On the other hand, Chinese Totok are pure-blood Chinese and born in China. Totok also refers to those who still practice Chinese cultures and speak Chinese or one of the Chinese dialects.

Suryadinata's study found that the Chinese in Indonesia also contributed to the voice of nationalism. In 1932, for example, the Chinese Indonesian Party (Partai Tionghoa Indonesia or PTI) was first established to oppose Chung Hwa Hui, a Chinese political organization that supports Dutch colonialism. PTI asked the Chinese in the Dutch East Indies to identify themselves as Indonesians, approve the efforts to form a government, and declare independence through constitutional means. PTI is anti-Dutch and rejects any forms of imperialism in Indonesia as their home country (Suryadinata, 2002).

The PTI collaborated with the national movement in attempts to fight for Indonesia's independence from the Dutch and Japan. In addition to the PTI, a fair number of Chinese ethnicities in Indonesia have been involved in the national movements to establish nationalism in Indonesia. They have also participated like local people to achieve independent and sovereign Indonesia. For example, several Chinese-Kwee Thiam Hong, Oey Kay Siang, John Lauw Tjoan Hok, Tjio Djien Kwie-participated in the Youth Pledge, laying an essential foundation for the birth of Indonesia. Besides, four other Chinese joined the Indonesian Independence Preparatory Investigation Agency (BPUPKI), namely Oei Tjong Hauw, Oei Tiang Tjoei, Mr. 
Tan Eng Hua, and Liem Koen Hian. There was also a Chinese who formalized the 1945 Constitution in the Preparatory Committee for Indonesian Independence (PPKI), namely Jap Tjwan Bing.

Moreover, there was Sin Sit Po newspaper, which served as an Indonesian-Chinese printed media reporting news on the national movement and introducing patriotism to the society. In 2009, the Indonesian government hailed Admiral Daniel Yahya Dharma or John Lie as the first Chinese-Indonesian to receive the national hero's title.

However, historically, Chinese have received many discriminatory treatments and pejorative stigma (Muzzaki, 2010). Social tensions often arise between Chinese and the local people, especially Islamic radical groups and those who suffered from business bankruptcy. According to Dahana (as cited in Mahfud, 2013), these phenomena might occur due to the lack of interactions between the two, resulting in stereotyping. Local people tend to view Chinese as only having commercial interests and stereotype them as "economic animals" since their activities are profit-oriented. They also did not mingle with the surroundings and did not have a nationalist spirit. This interaction pattern is exacerbated by the assumption that the Chinese also stigmatize the local people as slackers, extortionists, and other negative designations. Anti-Chinese riots were mostly due to these stereotypes and misperceptions (Al-Qurtuby, 2009).

The Chinese, including Chinese Muslims, have attempted to take measures to solve the problems. The community wants to eliminate all political and cultural issues by cultural assimilation between Chinese and Islamic values (Muzzaki, 2010). Such a phenomenon lays out a dilemma faced by the Chinese. As a minority, to be a good citizen, they have to comply 
with state regulations and establish better relations with local communities through a cultural approach in dealing with political domination. In this context, the cultural approach, for instance, is implemented by changing their name into more Indonesian, participating in the general election and social movement, commemorating Islamic days with the local people. The cultural approach was done to strengthen their social relationships with various social groups, to increase the socio-political significance of Chinese citizens, and to give them a bargaining position towards the state.

Mahfud, in this case, was trying to investigate the issue and report it in a book titled The Role of Cheng Ho Mosque: The New Silk Road, Indonesia-China Relations in Islamic Cultural Identity. In his study, Mahfud successfully traced the use of Cheng Ho Mosque to maintain cultural, social, educational, and religious values and its function as a medium to strengthen relations between Chinese and non-Chinese (Mahfud, 2014).

Rahmawati's study figures out that to prove their existence as a Muslim, the Chinese Muslims in Indonesia built Cheng Ho Mosque with typical Chinese architecture. Beside as a place to worship, this mosque also holds education and media publications. Although Rahmawati thoroughly explained Chinese Muslims in Indonesia and their roles in education and social aspects, she did not discuss how this community articulates their nationalist spirit in Indonesia (Rahmawati et al., 2018).

The study using a qualitative method looks at how the community constructs its national spirit (Dorovolomo et al., 2010). Thus, the concept of patriotism is not just a political reconciliation tool, and its articulation is not merely limited to celebrating national independence with fun activities 
that somehow show pseudo patriotism. On the other hand, the revolutionary patriotic characteristic is only relevant as a point of view in the context of independence war. In the contemporary era, the embodiment of more substantive patriotism concerns, stronger social solidarity, and high religious and cultural tolerance (Heryanto, 2019). In sum, hybrid patriotism can be formed and become a genuine nationalism for Chinese Muslims.

\section{B. Islam, China, and Indonesia: Historical Review}

The mainstream theory in the history of Islam in Indonesia concludes that Islam came from Arabic peninsula and Indian subcontinent. The first theory states that Islam originating from Arab, more specifically from Southern Arab such as Yemen and Hadhramaut, is proven by the major number of Shafi'i school followers similar to what occurs in Yemen. However, referring to the archeological proofs found in Gresik, East Java, there are pattern similarities between those in Maulana Malik Ibrahim' tombstone and those in Gujarat, India. There has not been a consensus whether Islam in Indonesia was from Arab, but then there are some proofs that Islam in Indonesia was from China.

This conclusion is strengthened by two historical facts. First, Islamic civilization in China was older than those in Indonesia. It can be seen from what year Islam came to these two areas. James Frenkel, in his research about Islam in China, found out that the story between Islam and China had been intertwined for a long time, even before the coming of Islam. The Arabs and Chinese were involved in trade relationships along the silk road since Han Dynasty (206 SM-221 M), delivering goods from and to ancient Mediterranean (Frankel, 2021). These trades continued up 
to the Tang period (618-906) that brought Muslims from Arab, Persia, Turkey, Middle East, and Central Asia to the heart of China, the capital of Tang city: Chang'an (Xian). It then continued during both the Umayyad and Abbasid caliphates up to the present day. In their historical process, the relationship between these two countries experienced ups and down: competitions, wars, trade cooperation, and diplomation (Frankel, 2016). Thus, it is understandable that China is one of the very old "Muslim's houses."

Second, popular history in Indonesia concludes that Islam came to Indonesia around the12th to 14 th century. That means there is a difference of five to six hundred years which allows Chinese Muslims to do Islamization in Indonesia. Some historians support this "Chinese theory" in the Islamization process in Indonesia, including Al-Qurtuby (2017); Ali, (2007); Graaf and Pigeaud (1984); Muljana (2010); and Sen (2010).

In a book titled Ming Shi (The History of Ming Dynasty) and Ying-Yai Sheng Lan, it is mentioned that the majority of Chinese Muslims had been living a more decent life in the harbour areas in Java, compared to the indigenous people (Mills, 1970; Groeneveldt, 1960;).

A historian and a novelist, Pramudya, mentions that there was a Chinese figure who played a significant role in cultivating Islam in Java in the 16th century. He is Liem Mo Han, to whom the local people called "Babah Liem." He was not only built up the Chinese's strength to fight against Portuguese who invaded Indonesia at the time but was also known as the architect of an ancient mosque in Java, e.g., Mantingan mosque in Jepara, Central Java. As a Chinese Muslim, Babah Liem was the leader of Nang Lung (South Dragon), an organization of Chinese diaspora that perpetuated their ancestor's civilization and cultures. Chinese living along northern Java respected him very much (Toer, 2001). 
However, the long history of Chinese existence in Indonesia should be messed up with a political strategy so that it leads to the negative stigma from local people towards the Chinese. The Sultans in Java made the Chinese as tax collectors in along the main roads, bridges, harbors, and markets. Seeing it as an effective way, both the Dutch and English used the same way in their territory in Indonesia. A racial incident towards the Chinese was a riot in Solo in 1912 and Kudus in 1918 of which one of the triggering factors was the impact of the government designed the Chinese as the "bad guy."

During the revolution era, several movements of antiChinese occurred in Tangerang in May-July 1946, Bagan Siapi-api in September 1946, and Palembang in January 1947. The racial sentiment towards the Chinese grows stronger in Indonesia due to the divided politics of President Soeharto. In a research entitled "Political Institutions and Ethnic Chinese Identity in Indonesia," Freedman (2003) mentions that Soeharto forces the Chinese to assimilate while identifying them as non-indigenous people at the same time.

Thus, in May 1998, anti-China outbreaks of violence reached its peak. Chinese Indonesians became rape and murder victims, and their homes and shops were burned. It may be because Chinese descendants take control of the Indonesian economy. Some of them were so rich, although they constitute only $2 \%$ of the Indonesian total population. It is primarily because a small number of Chinese in Indonesia gain investment facilities during the Soeharto era so that they can be very rich. These Chinese were then seen as the representatives of all Chinese, as a group that possess power and gain wealth in a deceitful way. The fall of Soeharto in 1998 highlighted these differences. 
Looking at this reality, it can be said that the assimilation process of Chinese descendants did not run smoothly in Indonesia, although they have been created one movement to end ethnic discrimination. This effort has also been done by Junus Jahya with other figures of Chinese descendants such as P.K. Ojong, Ong Hok Ham, Kwik Hway Gwan, and Harry Tjan Silalahi who initiate the Assimilation Charter in a seminar in Bandungan, Central Java in 1952. They defined assimilation as a process of Chinese descendants entering Indonesian and being accepted so that there were no more differences between indigenous and non-indigenous people as well as between the majority and minority.

For the Chinese, assimilation is an absolute requirement to reach prosperous and justice in Indonesia. Junus Jahya is a Chinese offspring named Lauw Tjhwan Thio who converted to Islam in 1979 with the assistance of Buya Hamka, a great Indonesian ulema. Buya Hamka also helped Junus Jahja to be one of the boards in Majelis Ulama Indonesia (MUI, or Indonesian Ulema Assembly) as the secretary.

Junus Jahja with other Chinese intellectuals emphasized that the only way for the Chinese descendants to be loyal to the country is by leaving their positions as a minority and assimilating completely to be "true" Indonesians. More specifically, Junus Jahja stated that to overcome "the Chinese problems," the Chinese should convert to the major religion in Indonesia, i.e., Islam, and he did so in 1979 to be a Muslim.

The Chinese are often regarded as foreigners in Indonesia. This concept of "foreigner" may be caused by the way the majority of people understand nationalism. For the Chinese Muslims being a nationalist, they should be an 
Indonesian first of which one of the ways is by assimilating either by converting to the major religion or changing their names to be more Indonesian. Shie Kim San, Chief of PITI Surabaya, did the latter by changing his name to Joko Slamet Sunarto, while Ong Khim Shui, a manager of Cheng Hoo Mosque Surabaya is called Hariyono Ong, and the Chief of the Haji Muhammad Cheng Hoo Indonesia Foundation, Lim Fuk San is called Hasan Basri.

Besides, after the fall of Soeharto, Chinese Muslims in Indonesia established an organization to identify themselves as both Muslim and Indonesian. Such organizations are Persatuan Islam Tionghoa Indonesia (PITI, Chinese Muslims Indonesia Association), Yayasan Abdul Karim Oei (Abdul Karim Oei Foundation), Chinese Muslims and Family, and Haji Muhammad Cheng Hoo Association. The above organizations play a significant role in the process of Islamization primarily for the Chinese who want to convert to Islam. However, their decision to convert to Islam may not be based on their concept of divinity that they believe is true, but more on the hope to be accepted as a part of Indonesia (Mahfud, 2013).

\section{Rethinking of Nationalism Concept}

Before we explain Indonesian nationalism, we need to understand that Indonesian society's socio-cultural dynamics have undergone drastic changes as a result of migration flows. This reality then gave rise to cultural assimilation between the newcomers (China, Arab, Europe, and India) and the local people, which had repercussions on constructing the national mind. The increasing presence and visibility of migrants and their descendants in Indonesia, in certain aspects, gave birth to their loyalty, social ties, customs, and language, which increasingly merged with the Unitary State of the Republic of 
Indonesia. It is there that we can find the socio-cultural basis of a more cosmopolitan conception of nationality.

Indonesians' patriotism is a response to realizing that ethnicity and religious identity need to be recognized to express their national spirit in their daily lives. During the process, Indonesia describes itself as a multicultural society reflected in Pancasila with its credo "Bhineka Tunggal Ika" (Unity in Diversity). This universal value then binds Indonesia as a nation with racial, ethnic, and cultural diversity. Instead of asserting itself as a monoculture country that often generates residual racial sentiment Indonesia is a country in a hybrid space. Various cultural and social identities influence people's social reality, so talking about Indonesia is as the same as talking about diversity (Zuhdi, 2018).

Some experts also define the concept of nationalism. Mulkhan (1996) said that "nationalism is an idea of national unity in a political area of statehood" (p. 71). Perry argues that "nationalism is a conscious bond shared by a group of people who share a common language, culture, and history characterized by mutual glory and suffering and bonding in a particular country" (p. 78). In the end, nationalism can be understood as an issue born in various ways, ranging from the similarity of history, culture, ideals, injustice, oppression, and resistance of a group of nations (Perry, 2013).

The historical similarity of oppression, imperialism, and mutual resistance reflects why the concept of nationalism is more important to be expressed (individually and socially) through good practices in everyday experience, rather than merely showing it at a particular moment, for example, on Independence Day. This is what we mean by substantive nationalism (Atanasovski, 2015). 
Revisiting the concept of nationalism becomes relevant because articulating the country's spirit should not be limited to the national anthem and its flag. Therefore, the idea of nationalism is prone to becoming a political hostage. A historian, Kartodirjo, expressed his concern about disputes of political elites' in Indonesia that shows the disharmony among the national leaders indicating conflict of interest rather than national solidarity. Kartodirjo (2001) considers that Indonesia's political elites do not have the nationalist ethos. In this context, Jatmiko considers that Indonesian nationalism today is experiencing erosion (Jatmiko, 2019).

Therefore, nationalism must be understood as a spirit that becomes a collective project to be always displayed in all lifelines: politics, economy, education, society, and culture. The Indonesian nation must be able to learn from several countries that have been devastated by their citizens who perpetuate civil war as to what happened in Syria, Iraq, Yemen, Afghanistan, and other Muslim majority countries, indicating never-ending conflicts. Disintegration in some countries may become a valuable lesson for Indonesia to maintain its existence. The disintegration in several countries is a valuable lesson for the Indonesian state to maintain its existence as a unitary state. The phenomenon of disintegration in Indonesia is felt to be getting stronger in various regions with the emergence of clashes between communities and social classes in society, especially clashes between indigenous people and those claimed as "outsider" such as Chinese, leading to social problems in Indonesia (Kusumawardani \& Faturochman, 2004).

Concerning the relationship between ethnicity and patriotism, Smith's idea is valuable, and he has possibly been a central figure in various debates in the field. Smith (1991), as quoted by Sayegh (2011), objects to the tendency to use the 
ideal patriotism, in his view, that creates confusion between this ideal type and the historical phenomena. For him, nationality is a territorial community bound by a collective memory to all ethnicities inhabiting a region. In other words, ethnic elements are required to develop nationalism in a country (Sayegh, 2011).

It then must be realized initially that there was an idea of nationality among Indonesian scholars, i.e., cosmopolitan, modern, progressive, and across ethnicities. However, since Indonesia won its independence, nationality has been understood narrowly. It tends to be understood in terms of tribal primordialism (Javanese) so that Indonesian nationalism seems to be Javanese-centric elitism. The nation is no longer understood as an ideal and collective work creating a plural, just, and civilized life for all. Today the nation is considered a heritage from the ancestors of certain circles. Some Indonesians feel they have special rights, exceeding the rights of the others who may also contribute to Indonesia's history.

Although nationalism in Indonesia emerges from resistance to colonialism, it is also influenced by a common identity and national solidarity among diverse tribes in Indonesia, who generally have different expressions of their love for the nation (Alfaqi, 2015). Thus, claiming one ethnicity to be not nationalist since they are not originally from Indonesia (in this case, the Chinese) is an action that may threaten national solidarity. Besides, this attitude is counterproductive to the concept of patriotism itself and even is not in accordance with the history of Indonesia that was manifested from the struggles of various ethnicities and religions (Nurhisam \& Huda, 2016). 
In the Indonesian context, it is also crucial to investigate nationalism from a religious perspective because the religion (teachings and figures) in Indonesia plays a role in developing the concept of nationalism. Thus, the relationship between religious practices and patriotism in Indonesia cannot be ruled out. On the contrary, throughout Indonesia's history, religious practice has become one of the most intimate meeting points between religiosity and nationalism (Cavanaugh, 2011; Husna \& Thohir, 2020)

Islam in the Indonesian context provides a significant role in building the spirit of patriotism. Moreover, Islam, through its values, e.g., tolerant, democratic, solidarity, and unity, can contribute positively to the national development. So, there were no clashes between Islam and Pancasila as the national principle due to similar values the two shares. It is understandable that mainstream Islamic organizations such as Nahdlatul Ulama (NU) and Muhammadiyah can accept Pancasila as the national ideology. An accommodating and tolerant Islam that has become a mainstream religious pattern in Indonesia can be a force in assembling the spirit of patriotism (Nurhisam \& Huda, 2016). It also needs to be highlighted here that patriotism in Islam is a spiritual feeling that emphasizes a sense of unity, love of the homeland, and willingness to sacrifice for the nation. Thus, nationalism for Indonesia Muslims is understood not only as a concept but also as an expression of faith.

From the above elaboration of the concept of nationalism, it can be said that patriotism is the nation's supreme loyalty. Such loyalty arises because of the awareness of a collective identity that is different from others. In most cases, it happens because of similar descent, language, or culture. However, the 
most powerful thing about nationalism is the willingness to unite. So that it can be concluded that nationalism is not a static but dynamic matter. One may come from China, Arab, or Europe, but due to their love to Indonesia, they contribute positively to the national development. For example, a Chinese named John Lie, an Arab named Abdurrahman Baswedan, and a Dutch named Ernest Douwes Dekker (Danudirdja Setiabudi) are national heroes as they also fought for the Indonesia's independence although they were not born in Indonesia. Simply put, contesting indigenous and nonindigenous people under the concept of nationalism may not be a relevant perspective.

The above explanation affirms that the construction of nationalism also needs to be attributed to the rapid growth of some identical and other social solidarity such as religion, social class, and ethnicity. As a multi-ethnic country, Indonesia cannot be seen to be having only certain ethnicities or indigenous people. Those in certain positions can embrace other identities and solidarity that all these social identities have similar rights to contribute to Indonesia. It is not meant to revive old primordialism, which is regional in nature. Thus, the construction of the nation needs to be seen from various perspectives. It can be argued that nationalism is constructed by a variety of measures, not merely limited to the expressions against colonialism and state ceremonies but also through religious expression which is not radical, far from racial sentiment, and able to build collective awareness to help each other (Umar, 2016).

The absurd assumption that nationalism only manifested in the struggle for independence, brotherhood, and sovereignty is only championed by elitist nationalists, whereas the voices of religious and ethnic groups also play 
an essential role in forming nation-states and even national solidarity. This reality only worries those who believe that a nation is an absolute, ahistorical, standard, and authentic social identity. Those, who imagine the nation as a naturally formed social group, even though the spirit of nationality has its own distinctive identity and character, are bound to a territorial area given by God, which is constructed by a diverse and complex social identity (Saekan, 2017).

In this context, patriotism was born in a hybrid space: tribal and religious socio-cultural movements with various devices as expressions of love to the homeland that continues to reproduce its dynamic, progressive nature. Patriotism is currently no longer relevant to be understood as a revolution towards decolonization. Nevertheless, as a cultural strategy and social project to continue committing and contributing to upholding the state's pillars, it is not only enlivened by incidental-ceremonial activities.

\section{Nationalism: Religious, Ethnicity, and Society as a Perspective}

For nearly two decades, the Chinese Muslim community has strengthened since the Organization of The Chinese Islamic Association of Indonesia (PITI) was founded and focused on social activities. For the Chinese, one way to minimize the anti_chine sentiment is by converting to a Muslim. Becoming a Muslim is considered as a last resort by the Chinese Muslims as a form of assimilating with the local people who are Muslim majority (Muzakki, 2010). Although there is no exact number of how many of them converting to Islam to date, the conversion seems to open a new way for their social life. Besides, Chinese Muslims serve as a subdivision of Chinese community in Indonesia. 
However, to be a Muslim may not be sufficient for them. They should also show the Islamic style that is in accordance with Indonesians. The Chinese Muslims should try to convince that their Islamic understanding is far from radicalism. So, it is no wonder if they also actively campaign for the spirit of nationalism through Islamic dakwah in accordance with the pillars of nationalism as in Pancasila (Mahfud, 2018). This commitment is carried out through a rigorous selection of preachers who can teach religion within the group. As a form of acculturation, they invite non-Chinese preachers such as the mainstream Islamic organization in Indonesia: Muhammadiyah and NU which are known to be having moderate Islamic perspectives.

PITI aims at realizing an Islam that is open, dialogical, and inclusive. This objective is translated through a mission: to unite Chinese Muslims with Indonesian Muslims, Chinese Muslims with Chinese non-Muslims, and Chinese with Muslims (Mahfud, 2013). PITI is a dakwah organization that has a mission to convey Islamic teachings, especially to the Chinese, and conduct coaching to guide Chinese Muslims to practice Islamic teachings in their non-Muslim environment. The above strategy is relevant to the purpose of establishing PITI, i.e., to manifest moderate, dialogic, and tolerant Islam. This purpose is formulated through the following missions: unifying Chinese and Indonesian Muslims, Chinese and nonChinese Muslims, and Chinese and Muslims. PITI is a preaching organization aiming to deliver Islamic teachings specifically for Chinese and guide the Chinese Muslims to practice Islamic teachings in their non-muslim environment.

PITI also provides mentoring and many activities that can encourage Chinese Muslims to socialize and interact with the local people, both in their neighborhoods and workforce. As 
a forum for the Chinese Muslim community, PITI also provides protection and assistance for those converting to Islam but who have problems with their families and social environment.

In Surabaya, the spread of Islam to the Chinese Muslim community is getting more robust through the Cheng Hoo Mosque built in October 2002. In this city, the Chinese Muslim community's population reaches 700 people, as stated by PITI Surabaya chairman Sie Kim San (Sie Kim San, interview, January 27, 2019). The Cheng Hoo Mosque in Surabaya was the first established, and there are 14 typical mosques all over Indonesia to date: 5 are in East Java (Surabaya, Malang, Pasuruan, Jember, and Banyuwangi).

Admittedly, Chinese in Indonesia, including Chinese Muslims, still hold their ancestors' traditions. Although they have been Muslims, it does not mean they no longer belong to their ethnics. It is no wonder that this community has two inherent cultural attributes: Muslim and Chinese. The identity in the Indonesian context becomes a unique matter because the majority of Indonesians are Muslims while Chinese are mostly non-Muslims. Thus, many consider them as a "double minority" meaning that they are minority in the context of ethnics in Indonesia and of religion within the Chinese themselves.

The chairman of PITI Surabaya, Shie Kim San, stated that "Chinese Muslims are everywhere but not everywhere" (Interview, December 19, 2019). It means that "Chinese Muslims are everywhere" in the social sense; it is a blending community, not exclusive, and able to interact with others. In fact, many Chinese Muslims are married to local people. For example, Hariyono Ong, a convert who manages Cheng Hoo Mosque Surabaya, is married to a woman from Bawean, Gresik, East Java. The Cheng Hoo Mosque in Surabaya is located in the neighborhood of non-Muslim Chinese. According to Shie 
Kim San, it shows that after being a Muslim, they do not avoid their fellow and try to interact with non-Muslim Chinese as a neighbor, relative, or family.

Meanwhile, establishing the Cheng Hoo Mosque, Chinese Muslims want to deliver messages to their fellow Chinese that becoming a Muslim does not erase their cultural identity as Chinese. This commitment to their ethnics can be seen from the building of the Cheng Hoo Mosque that interpolates with Chinese traditions and philosophy such as domination of red color, pat kwa in the Mosque rooftop, which symbolizes luck.

It is important to note that looking at Indonesian history, there is one situation that the Chinese want to achieve after the fall of the new order authoritarianism era, i.e., cultural identity. In this era, everything related to Chinese was prohibited, e.g., clothes, scripts, Chinese New Year celebrations, organizations, and so forth. On the other hand, this community is still often attributed by the local people as Christians, Confucianism, or Buddhist. Thus, the emergence of PITI after the fall of the new order era is used as a media to build the image of Islamic acculturation and play social roles within Indonesian society.

In relation to culture, Chinese Muslims strongly hold their ancestor's legacy. They still do dances such as Barongsai (Wu Shi; lion dance) and Liong (Nong Shi $U$; dragon dance). However, there is Islamic sharia that they must obey, which prohibits idolatry and acknowledging any power other than God. This means that the Chinese Muslims face problematic issues in addressing and believing in cultural traditions such as (a) the existence of rituals and symbolizing Barongsai with Confucian/Taoism and (b) the process of building a Chinese identity through the redefinition of Barongsai's value and its supporting factors that can bridge the theological and cultural divide (Arif et al., 2013). 
It is important to note that Islamic characteristics of Chinese Muslims, i.e., open, can be seen from their perspective in dealing with differences in the muslim society consisting of various schools and Islamic mass organizations. PITI and the Cheng Hoo Mosque have a slogan, i.e., "stand before all groups". It means that the existence of PITI and Cheng Hoo Mosque is not only for certain Islamic groups in Indonesia.

The commitment to Islamic unity and solidarity is strengthened by an inscription located in front of the mosque. It is written in three languages: Chinese, Indonesian, and English, and contains nationalist spirit as the original saying follows:

“Geng Jing Wei Zhen Zhu Geng Jin Shou Jin Jie, Hu Xiang Zun Zhong, DuoDuo Gou Tong, Fa Yang Tuan Jie Jing Shen, Duo Yuan Liang Bie Ren, Duo Jie Na, Bie Ren De Yin Jian"

The above messages contain a message of a requirement to piety to the Creator, respecting each other, keeping the union, and accepting different opinions. Universal values such as tolerance, dialogic, and communication are a series of values that are prioritized by the Chinese Muslims in expressing Islam as seen through the motto above. Norms in the community of Chinese Muslims are the manifestation of the value system that will be their collective belief. These norms will gradually be directed to be collective agreement of the Chinese Muslims in Surabaya. In the end, the norms will be the religious reasoning which can be social control to behave according to the views of life of this community.

Therefore, it is logical that these norms in the next stage are used as ways of life and perspectives in socializing within the plural society as guidance to manifest good life. These norms as an instrument help the Chinese Muslims to develop 
their social competence to adjust their behavior in public places (Wahyudi \& Zuhri, 2019).

Related to the spirit of nationalism containing brotherhood and solidarity as described above, it is also stated by Hariyono Ong as the manager of Cheng Hoo Mosque Surabaya. He confirmed that they prohibit a speaker from offending political issues, racial-primordial sentiments nuanced ethnically and religiously, and conducting emotional provocations through materials that are still problematic in the community (Hariyono Ong, interview, October 19, 2019).

An extreme Islamic view has no place in this community because it will aggravate its social existence as a minority group. Exclusive religious opinions that tend to monopolize the truth will not be accepted amidst Indonesia's diverse social conditions, especially in the city of Surabaya as a basis of Chinese Muslims in East Jawa (Lindbeck, 1950).

By cooperating with local Islamic organizations such as Nahdlatul Ulama (NU) and Muhammadiyah, Chinese Muslims commit to similar inclusive attitudes (tasamuh) that are consistently campaigned by the two organizations. The refusal of Chinese Muslim authorities in Surabaya to preach Islamic teachings in controversial-antagonistic languages on the religious pulpit indicates that the refusal could show the Islamic extremism in this community and deteriorate their image in public places.

Chinese Muslims' attitudes, i.e., open to diversity and respect for plurality, can be seen at the Cheng Hoo Mosque inauguration on May 28, 2003. The event was attended by a number of key figures in Indonesia, such as the Indonesian Minister of Religions, the Islamic religious leaders of NU and Muhammadiyah, and the Chinese community of diverse religious backgrounds. 
Social work is a distinctive feature of the existence of the Chinese Muslim community in Surabaya. Through the Haji Muhammad Cheng Hoo Foundation, this community is active in carrying out social movements, including blood donations, donations for orphans, health checks, compensation for the poor and orphans, cheap groceries, and assistance for victims of natural disasters. According to Lim Fuk San, a form of dakwah is to provide the community's basic needs, not merely religious conferences. He believes that dakwah has to adapt to the context and social conditions. As the Daily Chairman of the Haji Muhammad Cheng Hoo Indonesia Foundation, he admitted that the social activities carried out by his community had succeeded in attracting sympathetic donors who entrusted their assets to be donated regularly through the Cheng Hoo Mosque Foundation (Lim Fuk San, personal communication, Januari 4, 2019).

Through a social role played by the Chinese Muslims in Indonesia, they attempt to develop the communal being to social being. In this context, their charity events are seen as a transmitter to connect the two (Back et al., 2012). Therefore, it is relevant for the social norms to be manifested through charity events. This contribution highlights that the Chinese Muslims in Indonesia have a significant role in helping the government distribute the economy. Hence, nationalism can be understood more substantively as a social role rather than an artificial, ceremonial event.

This argument also wants to emphasize that nationalism in the current context should be understood more substantively, through their active involvement in addressing national problems such as education, economy, and health. That is why nationalism should be understood not as a dead concept nor a heavenly discourse that 
only leads to the image of ideal world but should also be enlivened in the national life. Therefore, it is crucial to have an instrument to realize the more factual, empirical, and realistic values. The Chinese Muslims understand that charity events are more effective to be adopted as an instrument of national values that are not only limited to cognitive enrichment but also manifested in the empirical reality. In the next stage, this instrument changes the national values into personality, that is to make the Chinese Muslims to be having nationalist characteristics.

Jos Soetomo, one of the founders of the Cheng Hoo Surabaya Foundation, revealed that the involvement of Chinese Muslims in social activities was intended to show that their group was not exclusive and prove their commitment to Indonesian nationalism. Through the PITI organization and the Muhammad Cheng Hoo Foundation, Chinese Muslims in Indonesia want to promote better inter-ethnic relations with the local people and minimize discriminations they face either in the context of political rights, being a civil servant, or economic competition against the local people.

\section{E. Being Nationalist: Articulation of the Spirit of Chinese Muslim Nationality}

Chinese Muslims' identity in Indonesia is gradually constructed from dialogical entities of various existing identities. Various parties construct their socio-cultural entities: between public embodiment and personal affirmation, between collective construction and individual identification, between social discourse and daily practices, between global imagination and local variants, and between «being" with "becoming" (Weng, 2018). Whether locality, social class, religion, or daily practice, each of these entities is 
not an element that is vis a vis with nationalism, even though, on the contrary, they strengthen each other (Saekan, 2017).

The Chinese Muslims in Indonesia use this momentum to present themselves through the political party and social organization. PITI and Cheng Hoo Mosque Association serve as a platform for the biggest Chinese Muslim community in Indonesia to prove that they also have the right to positively contribute to the development of Indonesia. It is also to go against racial discrimination they face for 32 years (Weng, 2011).

Nevertheless, it should be emphasized that the identity of Chinese Muslims, especially being Islam and Chinese in Indonesia, is not a single entity. The two identities are various from the aspects of cultural-political orientation, religious organization affiliation, social-economy class, and their involvement in politics as well as difference across areas.

The hybrid identity above gave birth to scrambled hybrid nationalism that would have made Chinese Muslims in Indonesia better understand Indonesia as a "shared home." Rather than being trapped in a terminologically problematic "national culture", being a nationalist is about celebrating the motherland's love through social roles and articulating cosmopolitan religious ideas. This method is even more substantial than showing nationalism by simply using a symbol of celebration (Guo, 2015).

The various identity is then unified by the feeling of the Chinese Muslims that they view Indonesia as a home. Instead of being trapped in the "national culture" that is terminologically problematic, being a nationalist does not mean fading their cultural identity as Chinese but showing their cosmopolitan religious understanding. This way is seen as more substantial than showing nationalism only through celebrations (Guo, 2015). 
The character of cosmopolitanism of theChinese Muslims is seen as an affirmation that Islam should be expressed by upholding humanitarian values which are not only viewed as a moral call but the theological one. Cosmopolitan Muslims show their concerns towards humanity, such as equality before the law, protecting the people from tyranny, protecting the helpless' rights, and so forth. This attitude also counters the radicalism and terrorism phenomena in Indonesia which have not been fully tackled. The Chinese Muslims want to deliver the message that they are not part of the radical groups. Moreover, the Chinese Muslims even attempt to show the Islamic wisdom that they believe, and they also open to any civilization, such as the characteristics of local Muslims of Indonesia. This openness has made Muslims to be able to absorb any kind of cultural manifestation and knowledge from other civilizations.

The above understanding directs us to a perspective that Islam as a religion should not be attributed to or claimed to be owned by certain ethnics such as Arab or Middle East. It may close the other ethnics' creativity to believe that Islam is universal and relevant to all civilizations. Hence, Islam is understood and monopolized by a certain culture which narrows down Islam itself as a global and contextual religion.

This understanding is important because the concept of countries in the world, especially Southeast Asia, is often divided into two, consisting of an indigenous state and an immigrant state, which differ from each other. However, the concept of nationality in the Indonesian context may be inappropriate to be understood from the first concept's perspective. It is primarily because the country is not based on a particular tribe. Even if it is so, it will trap one in the social fragmentation between the "majority" and the "minority" that potentially may lead 
to increased disintegration (Miftah, 2016). On the contrary, Indonesia is more relevant in terms of being defined as a country that is constructed by the complexity of ethnicity, religion, and social class which ultimately forms its unique, special, and multicultural national characteristics. Hence, the credo of Indonesia as a "Bhineka Tunggal Ika" (Unity in Diversity) in Pancasila bridges racial and religious diversities in this country.

In the context of Chinese Muslim patriotism, it cannot be simply claimed that the sense of belonging to Indonesia as a shared home should be seen as a form of complex social identity construction. The following paragraph will illustrate how to view the characteristics of Chinese Muslim patriotism.

To construct the identity, Chinese Muslims in Indonesia published photos of the ancient mosque of Niu Jie (Beijing) in their self-published magazine, Cheng Hoo. It is the mosque that inspires the architectural design of Cheng Hoo Mosque in Surabaya. Inaugurated in 2002, the mosque is equipped with symbols and religious activities of local Muslims - NU and Muhammadiyah - to create a distinctive impression of their Islamic identity (Weng, 2019). By referring to Chinese Muslim traditions that they consider to have an older history than Islam in Indonesia, they assert their religious heritage and reorganize it into a new cultural identity.

The architectural design of the Cheng Hoo Mosque pertains the Chinese cultural identity because Chinese Muslims want to show that the mosque they built has three functions. Borrowing Knobler's term, the mosque was built with operational, environmental, and symbolic functions (Knobler, 1980).

The operational function means that the building is a place of worship and a "cosmopolitan space" where various 
cultural and religious identities meet. People from numerous countries and religions such as Malaysia, the US, Europe, and Africa visit and are allowed to enter the mosque to be introduced to the identity of the Chinese Muslims in Indonesia. The environmental function refers to the psychological response of the neighborhood people, mostly non-muslim Chinese, that the Chinese Muslims are not marginalized within their ethnic group. The symbolic function refers to the message they want to deliver, that a Chinese can also be a good Muslim where it is a rare occasion that the local Muslim may find.

Some Chinese Muslim leaders, especially those who are active in the Foundation of Haji Muhammad Cheng Hoo Indonesia, often provide financial support for leaders of both Provincial Branches of NU and Muhammadiyah to visit Hui Muslims in China, and vice versa. The other way around, the Chinese are also invited to regularly visit the Chinese Muslim community in Indonesia.

Chinese Muslims seem to be not only having inward bonding solidarity but also outward bridging solidarity among the citizens. Religious institutions in Indonesia play their role in developing the concept of nationalism in modern Indonesia. Indonesian Muslims mostly recognize the modern nationalism as a platform for national life without any longterm interest to change Indonesia to be a religious-based nationalist country. It is primarily because it is a form of ideological treason against the final form of Indonesia which had been agreed before, that Indonesia is not a country for specific groups, either ethnicity or religion

It then can be concluded that Chinese Muslims play transnational and local networks to construct the idea of nationalism on the one hand. On the other hand, they also try to form a cosmopolitan Islamic characteristic that is open 
to other nationality concepts (Weng, 2019). This attitude can counter one idea of Islamic groups who want to make Indonesia as a religion-based country.

Chinese Muslims' phenomena here further confirm that multiculturalism and nationalism may have a harmonious relationship. In other words, multiculturalism in the Indonesian context can be seen as a mode of negotiating the symbolic requirements of nationalism: the need for having a unifying narrative for the nation to resist and restrain dominance over internal ethnicities and races. To support pluralism, Chinese Muslims in Surabaya also continue to celebrate Chinese traditions such as Barongsai and Chinese New Year (Karsono, 2007), and celebrations of local Muslim traditions. Thus, instead of working against nationalism, multiculturalism attempts to build a more effective nationalism, accommodating the increasingly complex heterogeneous realities of the late 20th century (Ang, 2010).

Viewing the Chinese Muslims as a part of Indonesia highlights that multiculturalism and nationalism can have inseparable relations. In other words, multiculturalism in the context of Indonesia can be seen as a way to negotiate the requirement of symbolic nationalism: the need for a narrative to unify the nation against the domination over internal ethnicities and races.

The concept of nationalism is a flexible concept because it has traditionally aimed only to encompass indigenous people. In other words, a genuine nationalist must be a local native. On the one hand, this understanding may have some truth because it relates to territorial rights, but the important paradigm that needs to be understood is that nationalism is an imaginative concept that is instinctive; even Renan said nationalism is spiritual in nature (Renan, 1992). 
The concept of nationalism, which is understood as an attitude of soul and spirituality, is more flexible. Thus, nationality can be constructed through anthropological concepts, such as race, language, interests, religious closeness, geography, military needs, and social works (Putra et al., 2020). This paradigm leads us to conclude that nationalism itself is a hybrid concept that is proven by the Chinese Muslims at Surabaya in this study.

In addition, in principle, Chinese Muslim nationalism can be viewed in two aspects: the past and the present (Hanggara, 2018). Admittedly or not, as discussed in the introduction, ethnic Chinese share a rich historical heritage with Indonesia - the desire to live together, and the desire to continue investing in the legacy received together to form a multicultural civilization in Indonesia (Hyer, 2006).

The nation is the result of effort, sacrifice, and devotion that has long passed, like the historical traces that were performed by the Chinese ethnic group for the Indonesian people in coloring this country as a unitary state. The historical aspect is crucial, as this is where we can see the glory and heroism of great people. The past is the social capital upon which the concept of nationalism is based. According to essential conditions, seeing the past in an elaborate manner is the basis for becoming a people: having the same glory in the past and the desire to continue in the present and future.

\section{F. Conclusion}

This study finds that there has been a new cultural euphoria today called the Chinese Muslim tradition in Indonesia. This phenomenon forms a lively illustration of Indonesia's cultural identity. This community does not display excessive Chinese values, which triggers negative stereotypes 
about Chinese citizens who seem exclusive. In addition, there is one more important phenomenon depicting Chinese Muslim culture as a social reality in Indonesia. As part of Indonesia, Chinese Muslims have their own characteristics, traditions, and religious discourses that are compatible with the spirit of nationalism. They often incorporate national and local cultural elements to promote their existence in public spaces while adopting mainstream Islamic traditions in Indonesia. It seems that they also attempt to negotiate their identity and commitment to Indonesian nationalism.

Chinese Muslims in Indonesia, especially Surabaya, have shown their commitment to nationality more substantially, notably by inclusive Islamic expressions and contributions to social movements in education, culture, and charity. Being nationalist in this way is more essential than the articulation often shown by ceremonial and artificial events alone.

\section{REFERENCES}

Al-Qurtuby, S. (2009). The Tao of Islam: Ceng Ho and the legacy of Chinese Muslims in pre-modern Java. Studia Islamika, 16(1). https://doi.org/10.15408/sdi.v16i1.489

Al-Qurtuby, S. (2017). Arus Cina-Islam-Jawa. Elsa Press.

Alfaqi, M. Z. (2015). Memahami Indonesia melalui perspektif nasionalisme, politik identitas serta solidaritas. Jurnal Pendidikan Pancasila Dan Kewarganegaraan, 28(2), 111-116. http://journal.um.ac.id/index.php/jppk/ article/view/5451/2120

Ali, M. (2007). Chinese Muslims in colonial and postcolonial Indonesia. Explorations, 7(2), 1-22. http://hdl.handle. net/10125/2220 
Ang, I. (2010). Between nationalism and transnationalism: Multiculturalism in a globalising world. Institute for Culture and Society Occasional Paper 1.1, 1(1), 1-14. https://doi.org/10.4225/35/57a94f550f198

Atanasovski, S. (2015). Hybrid affects of religious nationalism: Pilgrimages to Kosovo and the soundscapes of the utopian past. Southeastern Europe, 39(2), 237-263. https://doi.org/10.1163/18763332-03902005

Back, L., Bennett, A., Edles, L. D., Gibson, M., Inglis, D., Jacobs, R., \& Woodward, I. (2012). Cultural sociology an introduction. In Wiley-Blackwell. Blackwell Publishing.

Cavanaugh, W. T. (2011). The myth of religious violence. The Blackwell Companion to Religion and Violence, 23-33. https://doi.org/10.1002/9781444395747.ch2

Mahfud, C. (2013). Manifesto politik Tionghoa di Indonesia. Pustaka Pelajar.

Dorovolomo, J., Phan, H. P., \& Maebuta, J. (2010). Quality lesson planning and quality delivery: Do they relate? International Journal of Learning, 17(3), 447-456. https: / / doi.org/10.18848/1447-9494/CGP/ v17i03/46955

Frankel, J. (2021). Islam in China. I.B. Tauris.

Frankel,J. D. (2016). Chinese-Islamic connections: An historical and contemporary overview. Journal of Muslim Minority Affairs, 36(4), 569-583. https://doi.org/10.1080/1360 2004.2016.1248175

Freedman, A. (2003) Political institutions and ethnic Chinese identity in Indonesia, Asian Ethnicity, 4(3), 439-452, DOI: $10.1080 / 1343900032000117259$

Graaf, H. .de, \& Pigeaud, T.. (1984). Chinese Muslims in Java in the 15th and 16th centuries: The Malay annals of Semarang 
and Cerbon (M. C. Ricklefs (ed.)). Monash Papers on Southeast Asian Melbourne: Monash University.

Groeneveldt, W. . (1960). Historical notes on Indonesia and Malaya compiled from Chinese sources.

Guo, Y. (2015). Rethinking nation and nationalism. In cultural nationalism in contemporary China (pp. 9-23). POMEPS: the Institute for Middle East Studies at the George Washington University. https://doi. org/10.4324/9780203300480_chapter_1

Hanggara, A. (2018). Nasionalisme etnis Tionghoa di Indonesia. Equilibrium: Jurnal Penelitian Pendidikan Dan Ekonomi, 14(02). https://doi.org/10.25134/equi. v14i02.1129

Hapsari, R. D. (2016). Bibit nasionalisme di kalangan penduduk Tionghoa di Indonesia. Politiva, 7(2), 255-270.

Heryanto, A. (2019). Pasca-nasionalisme. https:// arielheryanto.com/2016/03/04/pasca-nasionalisme/

Husna, U., \& Thohir, M. (2020). Religious moderation as a new approach to learning Islamic religious education in schools. Nadwa, 14(1), 1999. https://doi.org/10.21580/ nw.2020.14.1.5766

Hyer, E. (2006). China's policy towards Uighur nationalism. Journal of Muslim Minority Affairs, 26(1), 75-86. https:// doi.org/10.1080/13602000600738731

Jatmiko, M. I. (2019). Post-truth, media sosial, dan misinformasi: Pergolakan wacana politik pemilihan presiden Indonesia tahun 2019. Jurnal Dakwah Tabligh, 20(1), 21. https://doi.org/10.24252/jdt.v20i1.9529

Karsono, O. M. F. (2007). Chinese traditional practices by the Chinese Muslim community of Surabaya. In Humanity and Social Sciences Journal 2(2), pp. 110-113. 
Kartodirjo, S. (2001, April). Biografi Tokoh Nasional. Kompas.

Kuo, C. (2018). Religion, state, and religious nationalism in Chinese societies. In C. Kuo (Ed.), Religion and Nationalism in Chinese Societies. Amsterdam University Press. https://doi.org/10.2307/j.ctt1zkjzkd

Kusumawardani, A., \& Faturochman. (2004). Nasionalisme. Buletin Psikologi, 7(1), 38-48.

Lindbeck, J. M. H. (1950). Communism, Islam and nationalism. The Review of Politics, 12(4), 473-488.

Mahfud, C. (2014). The role of Cheng Ho mosque: The new silk road, Indonesia-China relations in Islamic cultural identity. Journal of Indonesian Islam, 8(1), 23-28. https://doi.org/10.15642/JIIS.2014.8.1.23-38

Mahfud, C. (2018). Chinese Muslim community development in contemporary Indonesia: Experiences of PITI in East Java. Studia Islamika, 25(3). https://doi.org/10.15408/ sdi.v25i3.6755

Miftah, M. (2016). Multicultural education in the diversity of national cultures. QIJIS (Qudus International Journal of Islamic Studies), 4(2), 167. https://doi.org/10.21043/ qijis.v4i2.1766

Mills, J. (1970). Ying-Yai Sheng-lan: The overall survey of the ocean's shores (F. Ch'eng-Chun (ed.)).

Muljana, S. (2010). Runtuhnya kerajaan Hindu-Jawa dan timbulnya negara-negara Islam di Nusantara [The fall of the Hindu-Javanese King- dom and the rise of Islamic states in the archipelago]. LKiS Yogyakarta.

Mulkhan, A. M. (1996). Nasionalisme, refleksi kritis kaum ilmuan. Pustaka Pelajar.

Muzakki, A. (2010). Ethnic chinese Muslims in Indonesia: An unfinished anti-discrimination project. Journal of 
Muslim Minority Affairs, 30(1), 81-96. https://doi. org/10.1080/13602001003650630

Muzzaki, A. (2010). Cheng Hoo mosque: Assimilating Chinese culture, Distancing it from the State. 71, 1-29. CRISE Working Paper. https://assets.publishing.service. gov.uk/media/57a08b38ed915d3cfd000be0/ workingpaper71.pdf

Nathan Knobler. (1980). Visual dialogue. Harcourt School.

Nurhisam, L., \& Huda, M. (2016). Islam Nusantara: A middle way? QIJIS (Qudus International Journal of Islamic Studies), 4(2), 152. https://doi.org/10.21043/qijis. v4i2.1763

Perkasa, A. (2012). Orang-orang Tionghoa dan Islam di Majapahit. Pustaka Ombak.

Perry, M. (2013). Peradaban barat, dari revolusi Perancis hingga zaman globalisasi. Kreasi Wacana.

Putra, I., Yusuf, R., Sanusi, \& Maimun. (2020). Nasionalisme etnis Tionghoa di kota Banda Aceh. Jurnal Civic Hukum, 5(2), 157-165. https://doi.org/10.22219/jch. v5i2.13534

Rahmawati, Yahiji, K., Mahfud, C., Alfin, J., \& Koiri, M. (2018). Chinese ways of being good Muslim: From the Cheng Hoo Mosque to Islamic education and media literacy. Indonesian Journal of Islam and Muslim Societies, 8(2), 225-252. https://doi.org/10.18326/ijims.v8i2.225-252

Renan, E. (1992). What is a nation? In Nation and Narration. https://doi.org/10.4324/9780203823064

Saekan, M. (2017). Islamic education unifying nation. QIJIS (Qudus International Journal of Islamic Studies), 5(2). https://doi.org/10.21043/qijis.v5i2.2484 
Sayegh, P. Y. (2011). Nationalism as a social imaginary: Negotiations of social signification and (Dis)integrating discourses in Britain, France and Poland. Political science. Université Jean Moulin - Lyon III. https://tel. archives-ouvertes.fr/tel-00617618v3

Sen, T. T. (2010). Cheng Hoo penyebar Islam dari China ke Nusantara. Mizan.

Suryadinata, L. (2002). Pemikiran politiketnis Tionghoa Indonesia 1900-2002. In L. Suryadinata (Ed.), Pemikiran Politik Etnis Tionghoa Indonesia 1900-2002. INTI \& LP3ES.

Suryadinata, L. (2010). Etnis Tionghoa dan nasionalisme Indonesia. Kompas.

Toer, P. A. (2001). Arus balik: Sebuah epos pasca kejayaan Nusantara di awal abad ke-16. Hasta Mitra.

Umar, A. R. M. (2016). A Genealogy of moderate Islam: Governmentality and discourses of Islam in Indonesia's foreign policy. Studia Islamika, 23(3), 399-433. https:// doi.org/10.15408/sdi.v23i3.3157

Weng, H. W. (2011). Negotiating ethnicity and religiosity: Chinese Muslim identities in post- new order Indonesia (Issue 2). Australian National University.

Weng, H. W. (2018). Chinese ways of being Muslim: Negotiating ethnicity and religiosity in Indonesia. NIAS Press.

Weng, H. W. (2019). Berislam ala Tionghoa. Mizan.

Winarto Eka Wahyudi, \& Zuhri, A. M. (2019). Teologi sosial Muslim Tionghoa: keimanan, identitas kultural dan problem eksistensial. Empirisma, 29(2), 103-112. https://doi.org/10.30762/empirisma.v29i2.2345

Zuhdi, M. (2018). Challenging moderate Muslims: Indonesia's muslim schools in the midst of religious conservatism. Religions, 9(10). https://doi.org/10.3390/rel9100310 